\title{
Protecting animals from mistreatment through private prosecutions in South Africa: A comment on the National Society for the Prevention of Cruelty to Animals $v$ Minister of Justice and Constitutional Development 20161 SACR 208 (SCA)
}

\author{
Jamil Ddamulira Mujuzi
}

\begin{abstract}
The general rule in South Africa is that, when an offence is committed, the suspect has to be prosecuted by a public prosecutor. However, there is an exception whereby a victim of crime is permitted to institute a private prosecution if the prosecutor has declined to prosecute. South African law allows natural, but not juristic, persons to institute private prosecutions. In the case examined in this note, the appellant argued that the law prohibiting juristic persons from instituting private prosecutions is discriminatory. The Supreme Court of Appeal held that private prosecutions are only permitted on grounds of direct infringement of human dignity. This note argues that section 7 of the Criminal Procedure Act is unconstitutional for excluding juristic persons from instituting private prosecutions and recommends steps the appellant could take to institute private prosecutions against those who mistreat animals.
\end{abstract}

\section{Introduction}

The general rule in South Africa is that, when an offence is committed, the suspect has to be prosecuted by a public prosecutor. This is on the basis of section 179 of the South African Constitution and section 20 of the National Prosecuting Authority Act. ${ }^{1}$ However, as an exception to this general rule, where a victim of crime has no legal capacity, he / she or his / her representative is permitted to institute a private prosecution if the prosecutor has declined to prosecute. ${ }^{2}$ This is on the basis of section 7 of the Criminal Procedure Act (CPA),3 which provides:

“(1) In any case in which a Director of Public Prosecutions declines to prosecute for an alleged offence - (a) Any private person who proves some substantial and peculiar interest in the issue of the trial arising out of some injury which he individually suffered in consequence of the commission of the said offence; (b) a husband, if the said offence

\footnotetext{
1 Act 32 of 1998.

2 The prosecution policy of the National Prosecuting Authority provides for circumstances in which a public prosecutor may not prosecute an alleged offender even if there is evidence that he / she committed the offence in question. See "Prosecution policy" (2014), available <https://www.npa.gov.za/sites/default/files/Library/Prosecution\%20Policy\%20\%28Final\%20as\%20Revised \%20in\%20June\%202013.\%2027\%20Nov\%202014\%29.pdf> (last accessed 20 March 2017). ${ }^{3}$ Act 51 of 1977.
} 
was committed in respect of his wife; (c) the wife or child or, if there is no wife or child, any of the next of kin of any deceased person, if the death of such person is alleged to have been caused by the said offence; or (d) the legal guardian or curator of a minor or lunatic, if the said offence was committed against his ward, may, subject to the provision of section 9 and section 59(2) of the Child Justice Act, 2008, either in person or by a legal representative, institute and conduct a prosecution in respect of such offence in any court competent to try that offence."

Another type of private prosecution in South Africa is private prosecution by statutory right under either the CPA4 or other specific legislation. 5 Some statutes such as the National Environment Management Act and the Attorneys Act allow juristic persons to institute private prosecutions. However, it is beyond the scope of this note to discuss private prosecutions by statutory right.

In National Society for the Prevention of Cruelty to Animals $v$ Minister of Justice and Constitutional Development the Supreme Court of Appeal, commenting on section 7 of the CPA, observed that, "[t]he statutory provisions regulating private prosecution have been in place for almost 100 years". ${ }^{6}$ South African courts have held in several decisions that a victim of crime has a right to institute a private prosecution. 7 Unlike in some countries, such as the United Kingdom, Singapore, Kenya and Canada where juristic persons may institute private prosecutions, ${ }^{8}$ courts in South Africa have held that section 7 of the CPA cannot be interpreted as empowering juristic persons to institute private prosecutions. It is against this background that the National Society for the Prevention of Cruelty to Animals has approached the courts and argued, so far unsuccessfully, that section 7 of the CPA is unconstitutional for violating its right to equality. On 4 December 2015, the Supreme Court of Appeal held, in National Society for the Prevention of Cruelty to Animals $v$ Minister of Justice and Constitutional Development, that the appellant did not have the right to institute a private prosecution because "private prosecutions in terms of $\mathrm{s} 7$ of the CPA are only permitted on grounds of direct infringement of human dignity. This is the reason for $\mathrm{s} 7(1)(\mathrm{a})$ of the CPA and for the exclusion of juristic persons other than those mentioned in s 8 from instituting private prosecutions". ${ }^{9}$ The purpose of this note is to argue that the Supreme Court of Appeal's reasoning in this case is debatable. Specifically, the author argues that section 7 of the $\mathrm{CPA}$ is unconstitutional for excluding juristic persons from instituting private prosecutions. The author recommends some steps that could be explored by the National Society for the Prevention of Cruelty to Animals to enable it to institute private

\footnotetext{
${ }^{4}$ Id, sec 8.

${ }^{5}$ See for example: National Environmental Management Act (Act No 107 of 1998), sec 33; Prevention of Illegal Eviction From and Unlawful Occupation of Land Act, Act No 19 of 1998, sec 8; Extension of Security of Tenure Act 1997, sec 23; and Attorneys Act, 1979, sec 46A.

${ }^{6}$ National Society for the Prevention of Cruelty to Animals v Minister of Justice and Constitutional Development 20161 SACR 308 (SCA), para 8.

7 See for example: Freedom Under Law v National Director of Public Prosecutions and Others 2014 (1) SACR 111 (GNP), para 190; Nundalal v Director of Public Prosecutions KZN and Others (AR723/2014) [2015] ZAKZPHC 28 (8 May 2015), paras 53-54; Delport and Others vS [2015] 1 All SA 286 (SCA), 2015 (1) SACR 620 (SCA), para 31; and Reynolds NO v Beinash and Another [1998] JOL 2274 (W) at 6.

${ }^{8}$ See generally JD Mujuzi "The right to institute a private prosecution: A comparative analysis" (2015) 4 International Human Rights Law Review 222.

${ }^{9}$ National Society for the Prevention of Cruelty to Animals, above at note 6, para 28.
} 
prosecutions against those who mistreat animals. It is important first to highlight other decisions, in chronological order, in which courts have held that juristic persons have no right to institute private prosecutions.

\section{Excluding juristic persons from instituting private prosecutions}

As mentioned above, section 7 of the CPA does not expressly state that a juristic person may not institute a private prosecution. In Barclays Zimbabwe Nominees (Pvt) Ltd $v$ Black the court dealt for the first time in South Africa with the issue of whether a company was "entitled to bring a private prosecution" 10 under section 7 of the CPA. The applicants had argued that the word "person" in section 7 included a juristic person. Their argument was based on the fact that, because the CPA did not define "person", the court, on the basis of one of the rules of statutory interpretation, ${ }^{11}$ had to rely on the definition of that word in section the 2(b) of the Interpretation Act. ${ }^{12}$ This section provides that, unless the context requires otherwise, the word "person" includes "any company incorporated or registered as such under any law". In disagreeing with the applicant's submission, the court held:

"There are two clear points of distinction. In the first place we are not here concerned with a situation where the statute simply refers to a 'person'. The word 'person' does not stand alone. It is necessarily qualified by the word which immediately precedes it. What we have to decide is what was meant by the words 'private person' in the context of s 7 ... Furthermore, s $7(1)$ provides that any person referred to in (a), (b), (c) or (d) may institute and conduct a prosecution '... either in person or by a legal representative' and it would, I think, be straining language to speak of a company instituting and conducting a prosecution 'in person'. In fact [the applicant] conceded that the use of the word 'private' in the phrase 'private person' precluded the inclusion of the classes of persons referred to in subpara (a) of the definition of 'person' in the Interpretation Act, namely 'any divisional council, municipal council, management board, or like authority'. That does not of course mean that the remainder of the definition cannot be applied ... If, however, one applies to s 7(1)(a) only that part of the definition of the word 'person' which includes a company, the section will then read 'any private person including any company incorporated or registered as such under any law, who proves' etc. Quite apart from the linguistic awkwardness of using the pronoun 'who' to refer to a company, the question would then arise as to whether the word 'private' also governs [a] company. Prima facie it would, in which case the section would apply only to private companies. This would create an anomaly since there would seem to be no reason in principle why a private company should be able to prosecute and a public company should not."13

The court concluded that:

"The general policy of the legislature is that all prosecutions are to be public prosecutions in the name and on behalf of the State ... The exceptions are firstly where a law expressly confers a right of private prosecution upon a particular body or person (these bodies and

\footnotetext{
10 Barclays Zimbabwe Nominees (Pvt) Ltd v Black 1990 (4) SA 720 (A) at 721.

${ }^{11}$ DG Kleyn and F Viljoen Beginner's Guide for Law Students (4th ed, 2010, Juta) at 56.

12 Act 33 of 1957.

13 Barclays Zimbabwe Nominees, above at note 10 at 724 .
} 
persons being referred to in section 8(2)) and secondly, those persons referred to in section 7 . There may well be sound reasons of policy for confining the right of private prosecution to natural persons as opposed to companies, close corporations and voluntary associations such as, for example, political parties or clubs." 14

It should be recalled that Barclays Zimbabwe Nominees (Pvt) Ltd v Black was decided before the 1996 South African Constitution (the Constitution) which, inter alia, provides that juristic persons, like natural persons, also have rights under the Constitution. Section 9 of the Constitution provides for the right not to be discriminated against. It was on the basis of section 9 that the applicant in National Society for the Prevention of Cruelty to Animals $v$ Minister of Justice and Constitutional Development and Another 15 challenged the constitutionality of section 7 of the CPA as interpreted in Barclays Zimbabwe Nominees (Pvt) Ltd $v$ Black. In the High Court the applicants argued that section 7 was discriminatory and therefore contrary to section 9 of the Constitution. Apart from agreeing with the reasoning in Barclays Zimbabwe Nominees (Pvt) Ltd $v$ Black, the High Court held that: "not all rights in the Bill of Rights are for the benefit of juristic persons. Section 8(4) of the Constitution provides that a juristic person is entitled to the rights in the Bill of Rights to the extent required by the nature of the rights and the nature of that juristic person. For example, rights to life and to human dignity cannot sensibly be applied to juristic persons."16

The court added that what the Constitution prohibited was unfair discrimination and, to determine whether the discrimination in question is unfair, the following criteria have to be used: “(a) the position of the complainants in society and whether they have been victims of past patterns of discrimination; (b) the nature of the provision and the purpose sought to be achieved by it; and (c) the extent to which the discrimination has affected the interests or rights of the complainant" ${ }^{17}$ In the light of these criteria, the court held that:

"Taking into account these guidelines, it appears that (a) above more appropriately applies to natural persons. However, insofar as it may be applicable to the applicant I have already indicated above that the applicant should be regarded as a public body. I am not aware whether the applicant is a victim of past patterns of discrimination. As far as (b) above is concerned, the nature of section 7 and the purpose thereof have already been considered above. It constitutes an exception to the constitutional imperative stipulated in section 179 of the Constitution. The purpose is, inter alia, to afford a way of vindicating 'imponderable interests' and to curb the propensity to resort to self-help if there is a refusal by the Director of Public Prosecutions to institute a prosecution. To put it differently, the purpose of section 7 is to allow a private prosecution only where private or personal interests are at stake, but to prevent other natural persons, as well as juristic persons, not having such interests from doing so. To allow all persons to undertake a private prosecution would be contrary to the constitutional imperative and would effectively create an alternative prosecuting system. As far as (c) above is concerned, the following should be pointed out. First, in considering the effect or extend [sic] of section

\footnotetext{
${ }^{14}$ Id at 726. This principle was also emphasized in Reynolds v Beinash 1998 JDR 0510 (W).

15 (29677/2013) [2014] ZAGPPHC 763 (8 October 2014).

16 Id, para 19.

17 Id, para 24.
} 
7(1)(a) one must take into account that not only juristic persons are excluded, but also other natural persons not referred to in the section. The right to institute a private prosecution is determined by a limitation clause which does not only differentiate between juristic and natural persons, but also between natural persons. Second, the criteria applied to achieve this differentiation are not arbitrary, but to serve a particular purpose, i.e. to exclude persons not having a personal interest linked to some injury individually suffered." 18

The court also held that, in the light of the fact that section 179 of the Constitution provides that South Africa shall have a single prosecuting authority, it was necessary "to strictly control the right of private prosecution".19 It was against this decision that the applicant appealed to the Supreme Court of Appeal in the case of National Society for the Prevention of Cruelty to Animals $v$ Minister of Justice and Constitutional Development. As had been the case in the High Court, the appellants argued in the Supreme Court of Appeal that section 7(1)(a) of the CPA was unconstitutional because it:

"[D]ifferentiates between natural persons on [sic] one hand and juristic persons on the other hand. There is no good reason for differentiating between the two classes of persons. As a result, the differentiation fails to serve a legitimate governmental purpose and is therefore irrational and noncompliant with the rule of law as an articulated standard in S 1(c) of the Constitution. Further, the differentiation fails to render both natural and juristic persons equal before the law and specifically denies juristic persons equal benefit of the law rendering the impugned provision non-compliant with the articulated standard in s 9(1) of the Constitution." 20

The appellant submitted that the court should excise the word "private" from the CPA. ${ }^{21}$ However, the respondents did not make submissions contesting the appellant's arguments and, as a result, the court observed that "[i]t is unfortunate that the respondents failed to deal with the merits and provide this court with the rationale for the limitation of private prosecutions" ${ }^{22}$. After discussing the relevant jurisprudence on equality and the fact that section 9 of the Constitution applies to juristic persons as it does to natural persons, the court observed that:

"Counsel for the appellant properly conceded that the regulation of private prosecutions is a legitimate governmental purpose. Therefore, the question is whether the provisions of $\mathrm{s}$ 7(1)(a) of the CPA are rationally connected to this purpose. The rationality threshold is low. The connection must not be arbitrary but must be based on a reason that does not have to be the most efficient or the only reason. Put differently, the question is whether there is an acceptable reason for the limitation of private prosecutions contained in $\mathrm{s}$ 7(1)(a). This question must be answered within the context of the whole of s 7 and s 8 of

\footnotetext{
18 Id, paras 25-26.

19 Id, para 27.

${ }^{20}$ National Society for the Prevention of Cruelty to Animals, above at note 6, para 6.

21 Ibid.

22 Id, para 29.
} 
the CPA, s 179 of the Constitution and the provisions of the N[ational] P[rosecuting] A[uthority] Act." 23

The court then dealt with the role of the National Prosecuting Authority (NPA) and the circumstances in which a public prosecutor's decision whether or not to prosecute may be reviewed by either the national director of public prosecutions (DPP) or the courts. ${ }^{24} 24$ It is against that background that it held that, "[i]t follows that a decision of the prosecuting authority not to prosecute, which of course is a prerequisite for a private prosecution in terms of s 7(1) of the CPA, must be made for a good reason. Against this background the conclusion that private prosecutions should be limited to exceptional cases, cannot be faulted. The exceptions are those found in subsecs 7(1) and 8 of the CPA". ${ }^{25}$

Implied in this reasoning is that a victim of crime has three options should the prosecuting authority decide not to prosecute the alleged perpetrator: approach the national DPP and ask him to review and set aside the prosecutor's decision not to prosecute; approach a court of law to have the decision reviewed; or institute a private prosecution. The court also held that "[t]he effect of s 7(1) of the CPA is to permit private prosecutions only where private and personal interests are at stake". ${ }^{26}$ The court concluded that:

"In the final analysis, private prosecutions in terms of $\mathrm{s} 7$ of the CPA are only permitted on grounds of direct infringement of human dignity. This is the reason for s 7(1)(a) of the $\mathrm{CPA}$ and for the exclusion of juristic persons other than those mentioned in $\mathrm{s} 8$ from instituting private prosecutions. Human dignity is a foundational value of our Constitution. To allow for private prosecutions other than in terms of s 8 of the CPA only on grounds of direct infringement of human dignity, is for the reasons mentioned, rationally related to the legitimate government purpose of limitation of private prosecutions. I therefore find that s 7(1)(a) of the CPA is not unconstitutional." ${ }^{27}$

This article now analyses the court's ruling.

\section{Analysis}

The most important reason why the National Society for the Prevention of Cruelty to Animals approached the courts is because it would like to institute private prosecutions against people who allegedly mistreat animals. The challenge is that, unlike some legislation that empowers juristic persons to institute private prosecutions, ${ }^{28}$ the Societies for the Prevention of Cruelty to Animals Act ${ }^{29}$ does not empower the National Society for the Prevention of Cruelty to Animals to do so. One has to revisit history to understand why this organization does not have the right to institute private prosecutions. In

\footnotetext{
${ }^{23}$ Id, para 19.

${ }^{24} \mathrm{Id}$, paras 20-24.

${ }^{25} \mathrm{Id}$, para 25.

${ }^{26}$ Id, para 26.

27 Id, para 28.

${ }^{28}$ See above at note 5 .

${ }^{29}$ Act No 169 of 1993.
} 
National Society for the Prevention of Cruelty to Animals $v$ Minister of Justice and Constitutional Development, the Supreme Court of Appeal stated that:

"In the context of the prevention of cruelty to animals, the Prevention of Cruelty to Animals Act 8 of 1914 (the Prevention of Cruelty to Animals Act) applied. This Act was repealed by the Animal Protection Act in 1962. Before its repeal, s 12 of the Prevention of Cruelty to Animals [Act] authorised the society for the prevention of cruelty to animals [sic] to privately prosecute offenders ... It appears therefore that historically, the predecessor of the appellant had the right specially conferred by statute, to privately prosecute offenders. This power is not conferred by the Animal Protection Act or the [Societies for the Prevention of Cruelty to Animals] Act."3o

The court did not explain why the Animal Protection Act and the Societies for the Prevention of Cruelty to Animals Act do not confer on the National Society for the Prevention of Cruelty to Animals the power to institute a private prosecution. This could be the reason why some commentators have argued that one of the options available to the National Society for the Prevention of Cruelty to Animals is to approach Parliament to amend "the [Animal Protection Act] to reintroduce the power of the National Society for the Prevention of Cruelty to Animals to institute private criminal proceedings which was in the 1914 Act but which lacuna was probably inadvertently omitted from the 1962 Act". ${ }^{1}$ It is argued that the drafting history of the 1962 Animal Protection Act does not support the submission that power for the National Society for the Prevention of Cruelty to Animals to institute private prosecutions "was probably inadvertently omitted from the 1962 Act”. The drafting history shows that it was a conscious decision by the then minister of justice and members of Parliament, "fully" supported by the then Federation of Societies for the Prevention of Cruelty to Animals. ${ }^{2}$ It should be recalled that the Animal Protection Bill was tabled before the National Assembly as a private member's bill in February 1962.33 Section 13(1) of the bill provided that: "[a]ny Society for the prevention of cruelty to animals which is registered under ... the Act, may, by any person authorized thereto in writing under the hand of the chairman or secretary thereof, prosecute for any offence against this chapter and the provisions of any law relating to private prosecutions shall apply to all such prosecutions." 34

The then minister of justice objected, inter alia, to the inclusion in the act of a provision empowering the societies to institute private prosecutions. He submitted that:

"This principle that private individuals should be allowed to bring prosecutions in the courts without restriction is not one which I can accept. Hon members will realize at once what it may lead to and what repercussions it will eventually have. The usual safety valve as far as private prosecutions are concerned namely, that it is only when the AttorneyGeneral and the prosecutor have refused to prosecute and have given a certificate to that

\footnotetext{
${ }^{30}$ National Society for the Prevention of Cruelty to Animals, above at note 6, para 11.

${ }^{31}$ G Fraser and V Fraser "If only the SPCA were a company ..." (9 December 2015) Legal Brief

Today.

32 Debates of the National Assembly (Hansard) (11 May 1962) at 5516.

33 Id at 916. It was introduced by Hon Gay.

34 Id at 929.
} 
effect, that the private individual can go to court, does not apply here. The principle contained in this section is not one which I can accept." 35

Because of the minister of justice's objections to the bill, including regarding private prosecutions, the bill was withdrawn at a later stage. ${ }^{36}$ After almost three months, it was reintroduced in Parliament after the section on private prosecutions had been deleted. 37 It is against this background that the minister of justice submitted that: "Hon members will recall that in the other Bill there was ... a principle in respect of private prosecutions. That principle has now been excluded from this Bill. I tell my $[\mathrm{H}]$ on members that the Federation of Societies for the Prevention of Cruelty to Animals fully approves of that principle not being included in it”. 38

It is against that background that the Society for the Prevention of Cruelty to Animals was deliberately deprived of the power to institute private prosecutions. It should also be recalled that the drafting history of the Societies for the Prevention of Cruelty to Animals Act is silent on why the National Society for the Prevention of Cruelty to Animals does not have the power to institute private prosecutions. ${ }^{39}$ As mentioned earlier, in National Society for the Prevention of Cruelty to Animals $v$ Minister of Justice and Constitutional Development the Supreme Court of Appeal held that the appellant did not have the right to institute a private prosecution because "private prosecutions in terms of $\mathrm{s} 7$ of the CPA are only permitted on grounds of direct infringement of human dignity. This is the reason for $s$ 7(1)(a) of the CPA and for the exclusion of juristic persons other than those mentioned in s 8 from instituting private prosecutions". $4^{\circ}$ It is argued that this reasoning by the court is debatable, at least for the reasons outlined below. In order to put the discussion in context, it is apposite to repeat what section 7(1)(a) of the CPA states. It provides that "[i]n any case in which a Director of Public Prosecutions declines to prosecute for an alleged offence - any private person who proves some substantial and peculiar interest in the issue of the trial arising out of some injury which he individually suffered in consequence of the commission of the said offence" may institute a private prosecution.

The first point to make is that section $7(1)(a)$ is not limited to offences that infringe human dignity. It is applicable to "any case" that the DPP has declined to prosecute. Whether or not the offence in question has infringed the victim's human dignity is not a pre-condition for a person to institute a private prosecution. Case law from South African courts shows that private prosecutions have been brought against people who have committed offences that have nothing to do with infringing the right to human dignity. These have included cases where someone sought to enforce the payment of a debt, ${ }^{41}$ and prosecuting the accused for submitting or relying on a false affidavit and making a false declaration..$^{2}$ Of course there have also been cases where private prosecutions have been

\footnotetext{
35 Ibid.

36 Id at 1217.

37 Id at 5515 .

38 Id at 5516.

39 Debates of the National Assembly (Hansard) (25 November 1993) at 14064-89.

${ }^{40}$ National Society for the Prevention of Cruelty to Animals, above at note 6, para 28.

41 Phillips v Botha 1999 (2) SA 555 (SCA); [1999] 1 All SA 524 (A).

42 Nundalal, above at note 7.
} 
brought against people who committed offences that directly infringed the victim's human dignity. These have included, for example, cases of rape. 43 Therefore, the argument that the infringement of the right to human dignity is a prerequisite for the institution of a private prosecution is too restrictive and not supported by South African case law on private prosecutions. Another challenge is that the Supreme Court of Appeal does not explain how the right to institute private prosecutions relates to the direct infringement of human dignity. Although the South African Constitutional Court has handed down several decisions on human dignity, 44 it has been argued that "we can be less certain of the meaning of the concept". 45 This is because "the Constitutional Court has not ventured a comprehensive definition of human dignity". ${ }^{46}$ One would have expected the court to explain in concrete terms the direct relationship between human dignity and private prosecutions. Before linking private prosecutions under section 7 to human dignity, the court first observed that "[t]he effect of s 7(1) of the CPA is to permit private prosecutions only where private and personal interests are at stake".47 Although juristic persons do not have "personal" interests, it can hardly be argued that they do not have private interests to protect as victims of crime.

The judgment is not clear on the legitimate government purpose for limiting private prosecutions generally and to natural persons in particular. The judge is very clear that the appellant had no problem with the need for the government to regulate private prosecutions. This should be understood against the background that, according to the Constitution and to the National Prosecuting Authority Act it is the NPA that has responsibility to prosecute all alleged offenders. This means that private prosecutions are an exception, as they have been since their introduction in South Africa. $4^{8}$ The appellant's argument was simple: why should the right to institute private prosecutions not also be extended to an association that protects the rights of animals where there is evidence that the NPA has declined to prosecute people who have committed offences against animals? However, it would appear from the comprehensive discussion of the NPA's role that the court was of the view that the purpose is to ensure that all prosecutions in the country are conducted by public prosecutors. In Barclays Zimbabwe Nominees (Pvt) Ltd v Black, the court did not state the legitimate government purpose why the right to institute private prosecutions should not be extended to private companies. The court stated that, "[t]here may well be sound reasons of policy for confining the right of private prosecution to natural persons as opposed to companies, close corporations and voluntary associations such as, for example, political parties or clubs".49 In National Society for the Prevention of Cruelty to Animals $v$ Minister of Justice and Constitutional Development, the government made no submissions relating to the rationale behind limiting the right to private prosecutions under section 7 of the CPA to natural persons. As the court observed "[i]t is unfortunate that the respondents failed to deal with the merits and provide this court with the rationale for the limitation of private prosecutions". ${ }^{\circ}$ This meant that the

\footnotetext{
43 Bothma v Els and Others 2010 (2) SA 622 (CC); 2010 (1) SACR 184 (CC); 2010 (1) BCLR 1 (CC).

44 I Currie and J De Waal The Bill of Rights Handbook (6th ed, 2013, Juta) at 250-57.

45 Id at 251.

46 Ibid.

${ }^{47}$ National Society for the Prevention of Cruelty to Animals, above at note 6, para 26.

48 Records of the Cape Colony (vol 21, 1827) at 124-25.

${ }^{49}$ Barclays Zimbabwe Nominees, above at note 10 at 726.

${ }^{50}$ National Society for the Prevention of Cruelty to Animals, above at note 6, para 29.
}

\section{https://repository.uwc.ac.za/}


court did not have the benefit of knowing the government's position on the issue. This could be an indication that the government does have a valid reason why juristic persons should be prevented from instituting private prosecutions.

As mentioned above, section 7 of the CPA does not expressly state that juristic persons shall not institute private prosecutions. It is the Supreme Court of Appeal (previously the Appellate Division) that has interpreted it as excluding juristic persons from instituting private prosecutions. In reaching its conclusion, the Supreme Court of Appeal relied on a judgment that was handed down before the Constitution had been enacted. It is argued that section 7 of the CPA, as interpreted to exclude juristic persons from instituting private prosecutions, is unconstitutional for violating the right to equality under section 9(3) of the Constitution. Section 9 of the Constitution prohibits unfair discrimination. For any discriminatory act to pass constitutional muster, it has to be justified under section 36 of the Constitution, which provides that:

"The rights in the Bill of Rights may be limited only in terms of law of general application to the extent that the limitation is reasonable and justifiable in an open and democratic society based on human dignity, equality and freedom, taking into account all relevant factors, including - (a) the nature of the right; (b) the importance of the purpose of the limitation; (c) the nature and extent of the limitation; (d) the relation between the limitation and its purpose; and (e) less restrictive means to achieve the purpose."

The judgment is silent on whether prohibiting juristic persons from instituting private prosecutions could be justified under section 36 of the Constitution. It has been argued that:

"Once it is established that a law of general application infringes a right protected by the Bill of Rights, the State or the person relying on the law may argue that the infringement constitutes a legitimate limitation of the right. Rights [some of them] are not absolute. They may be infringed, but only when the infringement is for a compellingly good reason. A compellingly good reason is that the infringement serves a purpose that is considered legitimate by all reasonable citizens in a constitutional democracy that values human dignity, equality and freedom above all considerations. ${ }^{1}$

In the light of the fact that there are no compelling reasons why juristic persons should not be permitted to institute private prosecutions under section 7 of the CPA, it is difficult, if not impossible, to justify such a limitation in the light of the jurisprudence emanating from South African courts on section 36.52 If there is a fear that juristic persons may abuse private prosecutions, there are safeguards in place to ensure that they do not do so. These include: the requirement that such prosecutions shall not be instituted without a certificate from the DPP; the fact that the DPP retains the right to take over a private prosecution for the purpose of continuing with it or stopping it; and that courts have the power to prevent any private prosecutor from abusing his right to

51 Currie and De Waal The Bill of Rights, above at note 44 at 171-72.
52 Id at 150-75. 
institute a private prosecution. In a nutshell, there is no justifiable reason why juristic persons should not be permitted to institute private prosecutions.

Another difficulty with the Supreme Court of Appeal judgment is its heavy reliance on the case of Barclays Zimbabwe Nominees (Pvt) Ltd $v$ Black. Although the court in this case dealt with the issue of juristic persons to institute private prosecutions, the facts of the two cases are distinguishable. This is because in Barclays Zimbabwe Nominees (Pvt) Ltd $v$ Black a private company had instituted a private prosecution for its private gain: to have the person who had committed an offence against it punished and for the company to recover its money. On the other hand, in National Society for the Prevention of Cruelty to Animals $v$ Minister of Justice and Constitutional Development the appellant brought a private prosecution in the interest of the public, to protect animals and reduce animal cruelty. If the appellant is not permitted to institute private prosecutions against those whom the DPP has declined to prosecute for committing crimes against animals, this means that those who commit such offences will escape the consequences of their criminal acts. This is because the victims, that is the animals, for obvious reasons cannot bring a private prosecution; the owners are in most cases their abusers and therefore will not prosecute themselves; and the animal rights organizations have been barred from instituting private prosecutions.

One important issue that the Supreme Court of Appeal seems to have settled relates to the issue of a certificate before an individual institutes a private prosecution. It should be recalled that section $7(2)(b)$ of the CPA provides that "[t]he [DPP] shall, in any case in which he declines to prosecute, at the request of the person intending to prosecute, grant the certificate referred to in paragraph (a)". In 2009 a single High Court judge held that, before the DPP can issue a certificate to a victim of crime to institute a private prosecution, he had to be satisfied that the applicant has a substantial and peculiar interest in the matter.53 In 2015 another High Court decision (of the full court) held that the court and not the DPP must be convinced that the applicant has a substantial and peculiar interest in the matter.54 In National Society for the Prevention of Cruelty to Animals $v$ Minister of Justice and Constitutional Development, the Supreme Court of Appeal held that " $[\mathrm{t}]$ he prosecuting authority is obliged to furnish a certificate called nolle prosequi to someone who wishes to prosecute privately". 55

Some people have argued that, had the applicant in this case been a company, the court would probably have come to a different conclusion. ${ }^{6}$ This is because, the authors argue, section 19(1)(b) of the Companies Act provides that a company "has all of the legal powers and capacity of an individual”. In order to appreciate this argument, it is important to reproduce section 19(1). This section provides, inter alia:

"From the date and time that the incorporation of a company is registered, as stated in its registration certificate, the company - (a) is a juristic person, which exists continuously

\footnotetext{
53 Singh v Minister of Justice and Constitutional Development and Another (5072/05) [2006] ZAKZHC 20 (5 May 2006).

${ }^{54}$ Nundalal, above at note 7.

55 National Society for the Prevention of Cruelty to Animals, above at note 6, para 9.

56 Fraser and Fraser "If only the SPCA", above at note 31.
} 
until its name is removed from the companies register in accordance with this Act; (b) has all of the legal powers and capacity of an individual, except to the extent that - (i) a juristic person is incapable of exercising any such power, or having any such capacity; or (ii) the company's Memorandum of Incorporation provides otherwise."

It could be argued that, notwithstanding section 19, companies still do not have the right to institute private prosecutions. This is for two reasons. First, by the time the Companies Act was enacted, jurisprudence from South African courts was very clear that companies did not have the power to institute private prosecutions. If the legislature wanted to confer this power on companies, it would have stated so expressly in the Companies Act. Secondly, section 19(1)(b) provides that a juristic person "has all of the legal powers and capacity of an individual, except to the extent that - (i) a juristic person is incapable of exercising any such power". There are at least two ways in which a juristic person may be incapable of exercising a power: where it is incapable of exercising the power because of the nature of the power; and where the incapacity to exercise the power is a result of a law that prohibits the company from exercising the power. This means that the law makes the company incapable of exercising the power although the company would have been able to exercise the power had the law not prevented it from doing so. In other words, any attempt by the company to exercise the power would be unlawful. This is the case with private prosecutions.

\section{Conclusion}

In the light of these arguments, the following options are submitted to enable juristic persons to institute private prosecutions in South Africa. The first is for the appellant to appeal to the Constitutional Court for the court to settle the matter once and for all. However, the challenge with this option is that there is no guarantee that the Constitutional Court will hold that juristic persons have a right to institute a private prosecution. Nevertheless, this option is worth pursuing. According to section 167 of the Constitution, the Constitutional Court has jurisdiction over constitutional matters 57 and in any matter that "raises an arguable point of law of general public importance which ought to be considered by that Court". ${ }^{8}$ Commenting on its jurisdiction, the Constitutional Court recently held that:

"[16] This Court has not yet determined the full scope of its new jurisdiction or definitively granted leave to appeal on the basis of section 167(3)(b)(ii). Reduced to bare essentials, this section provides for this Court to grant leave if - (a) the matter raises an arguable point of law; (b) that point is one of general public importance; and (c) the point ought to be considered by this Court. [17] What is the import of the words 'which ought to be considered by that Court' in section 167(3)(b)(ii)? Although a point of law may be both arguable and of general public importance, there may be factors that militate against its receiving the attention of this Court. It seems to me that, on this, some of the factors that are of relevance to the interests of justice factor in the context of our jurisdiction based on constitutional matters may find application [sic]. [18] To summarise, a holding that a matter raises an arguable point of law of general public importance does not inexorably

${ }^{57}$ Constitution, sec 167(3)(b)(i).
58 Id, sec 167(3)(b)(ii). 
lead to a conclusion that the matter must be entertained. Whether the matter will, in fact, receive our attention will depend on the interests of justice, a subject I deal with later." 59

It is argued that the appellant's case not only raises a constitutional issue, that is, whether the fact that juristic persons are not permitted to institute private prosecutions is contrary to section 9 of the Constitution, it also "raises an arguable point of law of general public importance which ought to be considered by that Court". ${ }^{60}$ The point in question is whether there is a legitimate reason to prohibit juristic persons from instituting private prosecutions. This is an important issue in the light of the facts that: juristic persons are also sometimes victims of crime who may wish to prosecute those who have committed offences against them, should the state decline to prosecute; some of them, for example the appellant in National Society for the Prevention of Cruelty to Animals $v$ Minister of Justice and Constitutional Development, play vital public roles such as protecting animals from abuse; and that, in many jurisdictions, including some in Africa, laws permit juristic persons to institute private prosecutions. This means that the government would have to justify why in a democratic society, such as South Africa, juristic persons should still be barred from instituting private prosecutions.

The other approach would be for the legislature to amend the relevant legislation and expressly empower private companies and other juristic persons to institute private prosecutions. This has already been done in the past, for example by inserting section 49A into the Attorney's Act to empower the Board of Control to institute private prosecutions. ${ }^{61}$ Amending or enacting legislation expressly to empower juristic persons to institute private prosecutions would settle this issue once and for all. The third option would be to challenge the validity of the public prosecutor's decision not to prosecute. Although the Constitution and the NPA Act are very clear that prosecutors are supposed to be independent and prosecute without fear, favour or prejudice, there is growing jurisprudence from South African courts, including the Supreme Court of Appeal, 62 to the effect that a public prosecutor's decision not to prosecute or to discontinue a prosecution is not beyond scrutiny. The decision may be challenged on grounds including irrationality, illegality and unreasonableness. Where a public prosecutor's decision not to prosecute has been set aside, the charges in question are automatically reinstated. As the Supreme Court of Appeal held in National Director of Public Prosecutions and Others $v$ Freedom Under Law:

\footnotetext{
${ }^{99}$ Paulsen and Another v Slip Knot Investments 777 (Pty) Limited 2015 (3) SA 479 (CC), paras 16-18. ${ }^{60}$ In Mashongwa v PRASA (CCT03/15) [2015] ZACC 36 (26 November 2015), para 15, the court held that "this application raises a constitutional issue. It also raises an arguable point of law of general public importance relating to PRASA's legal obligations to protect its rail commuters from harm".

${ }^{61}$ Sec 49A provides: "Notwithstanding the provisions of sec 76, the board of control may, by any person authorized thereto in writing by the chairperson, and upon written notice to the society of the province concerned, institute a private prosecution for the misappropriation

or theft of property or trust money, and the provisions of section 8 of the Criminal Procedure Act, 1977 (Act No 51 of 1977), and any other law relating to private prosecutions shall apply to such prosecution as if the board of control is a public body."

${ }^{62}$ See for example: National Director of Public Prosecutions and Others v Freedom Under Law 2014 (4) SA 298 (SCA), 2014 (2) SACR 107 (SCA), [2014] 4 All SA 147 (SCA); Zuma v National Director of Public Prosecutions [2009] 1 All SA 54 (N), 2009 (1) BCLR 62 (N); and Democratic Alliance v Acting National Director of Public Prosecutions and Others (19577/2009) [2016] ZAGPPHC 255 (29 April 2016); Acting National Director of Public Prosecutions and Others v Democratic Alliance In Re: Democratic Alliance v Acting National Director of Public Prosecutions and Others (19577/09) [2016] ZAGPPHC 489 (24 June 2016).
} 
"[The] doctrine [of separation of powers] precludes the courts from impermissibly assuming the functions that fall within the domain of the executive. In terms of the Constitution the [National DPP] is the authority mandated to prosecute crime ... As I see it, the court will only be allowed to interfere with this constitutional scheme on rare occasions and for compelling reasons ... The setting aside of the withdrawal of the criminal charges ... [has] the effect that the charges ... are automatically reinstated and it is for the executive authorities to deal with them."63

In the author's opinion the most viable option would be for the legislation to be amended expressly to empower juristic persons to institute private prosecutions. ${ }^{64}$

63 Freedom Under Law, para 51.

${ }^{64}$ On appeal to the Constitutional Court, the court did not address the issue of the constitutionality of sec 7 of the Criminal Procedure Act because it did not consider it to be a live dispute. See National Society for the Prevention of Cruelty to Animals v Minister of Justice and Constitutional Development and Another 2017 (1) SACR 284 (CC), para 63. 